\title{
香港の民間語学学校で日本語を学習する高校生達の学び \\ 一構成主義の視点から一 \\ Learning experiences of high school students studying Japanese \\ at a private language school in Hong Kong:
}

A constructivist perspective

\section{瀬尾 匡輝 \\ 香港理工大学}

\section{要旨}

本稿では、民間語学学校で日本語を学ぶ 10 代の学習者 5 名に半構造化インタビュ 一を行い、彼・彼女らがどのように日本語を学習し、その経験をどう捉えているの か構成主義の観点から浮き彫りにする。

調査の結果、調査協力者らは、将来の仕事のための文化資本を獲得蓄積する投資 (Norton, 2000) として日本語学習を捉えていなかった。また、教科書や授業によ って提示される知識を体系的に学習しているだけではなく、今現在接しているアニ メや漫画、ゲーム、バラェティ番組といった日本のポップカルチャーから日本語を 学び、それを重視していた。また、年齢や社会経験が全く異なる学習者同士である にも関わらず、共に尊重し合い学びあう関係性がクラスメートや教師との間で構築 されていた。そして、そこで得られる学びは日本語に関するものだけではなく、日 本語学習を通した別の学び、例えば自分の理想とする将来像といった全人的学びで あった。

このように本調査に協力してくれた香港の民間語学学校で学ぶ 10 代の日本語学習 者達は、自ら構成主義の学習理論に基づく学習や知識の構築を行っていた。今後 益々多様化する日本語教育の現場において、構成主義の学習理論に基づく日本語教 育の現場がどのように構築されるべきか考えていかなければならないであろう。

キーワード :

海外の日本語教育、構成主義、高校生、学び 


\section{香港の民間語学学校で日本語を学習する高校生達の学び \\ 一構成主義の視点からー}

\section{瀬尾 匡輝 \\ 香港理工大学}

\section{1. はじめに}

筆者は現在香港の大学で主に初級授業を担当しているが、その中にはゼロ初級の クラスにも関わらず、民間の語学学校ですでに日本語を学習した者或いは大学で日 本語の授業を履修しながら語学学校に通う者も多く在籍している。香港ではこれま で、民間語学学校や大学付属の成人教育機関で学ぶ社会人学習者の数が全体の約 70 パーセントを占め、社会人学習者の存在が香港の日本語教育を象徵してきていた （国際交流基金，2011a）が、近年は香港における日本語学習者の低年齢化も指摘さ れ始めている（e.g. 国際交流基金，2011b; 梁，2012a）。特に、国際交流基金

（2011b）は、2000 年代後半の日本語能力試験 3 級、4 級の 20 歳未満の応募者数は 全体の 9 12\%であったのが、2010 年には、N4、N5 の応募者の 16\%を占めたというこ とを指摘した上で、香港では「初級学習者の中で若い世代の存在感が増してきてい る」と結論付けている。さらに、香港政府も 2009 年からの新高中課程（新後期中等 教育カリキュラム）で日本語科目を導入した学校に対して語学学習補助費を支給し たり、2012 年から実施されている香港中學文水憑（中等教育卒業統一試験）に受験 科目の 1 つとして日本語を含んだりと教育制度の面でも中等教育における日本語の 位置づけが強まりつつある。しかしながら、これまで香港の中等教育における日本 語教育の研究・調查はこれらの制度 (梁, 2012b) や中学校・高校の日本語科目の学 習者（宮崎, 2011）に関寸るものであり、香港の多くの 10 代の日本語学習者が学ん でいるとされる民間語学学校における調査は皆無であった。そこで本稿では、民間 語学学校で日本語を学ぶ 10 代の学習者に半構造化インタビューを行い、彼・彼女ら がどのように日本語を学習し、その経験をどう捉えているのか構成主義（e.g. 久保 田，2000）の観点から浮き彫りにする。

\section{2. 構成主義における学習観}

従来、学びとは教授者による一方的な知識の伝達であり、伝達する側が易しいも のから難しいものへと再構築した知識を切り分け、一斉授業といら形で行われてき た。このような学びではいかに標準化された知識を効果的に学び手の頭の中に取り 
込ませるかが目的となり、学習者には教授者の言うことを素直にこなす順応性が求 められていた。しかし、構成主義の学習理論では、学習という概念は社会的な建築 物である（有元，2011）と捉えられ、「知識は人と独立して存在することはなく、 周りの人やものとの相互作用の中で間主観的に構成されていく」（Steffe \& Gale, 1995, cited in 久保田，2012，p. 20）と理解されている。つまり、学びとは参加 者になるということであり、参加者間のやりとりの中で学習をしていく。そして、 構成主義の学習環境デザインでは、学び手の行為主体性が重要となり、学び手自身 が問題を見つけ、その問題解決の手段として周囲の人やものをリソースとして使う ことが求められている（久保田，2012）。このような学びでは、教授者の言うこと を素直に受け入れるだけではなく、時には教授者や標準的な知識を批判的に捉える 必要性があり、さらには、自らの考えに基づき行動する能動性や創造力というもの が必要とされる。

構成主義的学びの重要性は日本語教育でもすでに指摘されており、世界中で展開 されつつあるが（詳しくは 有田，2008）、香港の日本語教育現場ではどうなので あろうか。これまで香港の日本語教育においては、瀬尾（2011）や瀬尾・山口

（2012）がそれぞれ大学付属の社会人教育機関および独学で日本語を学ぶ上級学習 者のライフストーリーを通して彼・彼女らの日本語学習の経験について浮き彫りに はしているものの、それがどのような「学び」として学習者に捉えられているかは 明確にはなっていなかった。そこで、本稿では、構成主義の視点から香港の日本語 学習者（本稿では、10 代の学習者）の「学び」の経験を解棌することを試みる。

\section{3. 調查の方法}

本調査では、香港日本語学校（仮名）で日本語を勉強する 10 代の学習者 5 名に半 構造化インタビューを行った。香港日本語学校を調査協力校とした理由は、香港日 本語学校では、年少者のための日本語コースを開講しておらず、年齢の異なる社会 人と共に学習しているからである。調查協力者らによると、社会人と共に学習する コースを選んだのは、年少者用の日本語コースの多くが土曜日や日曜日に開講され ているために、学校の行事と重なることが多く、平日の夜しか日程を調整できなか ったからであるという。このことは香港の他の語学学校でも窥える現状であり、ま た、周囲の人やものをリソースとして使うことが求められる構成主義的な学習者観 （久保田，2012）から分析寸るのに適していると考えた。 


\section{瀬尾 匡輝：香港の民間語学学校で日本語を学習する高校生達の学び}

\section{一構成主義の視点からー}

調査協力者は調査協力校である香港日本語学校の学校長から推薦された香港の高 校生 5 名である。つまり、筆者は他の協力者を得ることが難しいときに用いられ、 抽出方法として調查しやすい調査協力者を選ぶ convenience sampling (Richards, 2003）を使用した。

表 $1:$ 調査協力者のプロフィール

\begin{tabular}{|c|c|c|c|c|c|}
\hline & 性別 & 年齢 & 日本語学習歴 & $\begin{array}{c}\text { 調查協力校での } \\
\text { 受講クラス }\end{array}$ & その他の事項 \\
\hline レーチェル & 女性 & 15 歳 & 中学 1 年から 3 年間 & 中級レベル & \multirow{4}{*}{$\begin{array}{l}\text { この } 4 \text { 名は、香港日本語 } \\
\text { 学校で同じ授業を受講し } \\
\text { ている。アリス、ジャッ } \\
\text { ク、ボブは同じ高校に通 } \\
\text { っいる（レーチェルは } \\
\text { 別の高校）。 }\end{array}$} \\
\hline アリス & 女性 & 15 歳 & 中学 2 年から 2 年間 & 中級レベル & \\
\hline ジャック & 男性 & 15 歳 & $\begin{array}{l}\text { 小学 } 6 \text { 年から } 4 \text { 年間 } \\
\text { (最初の独学期間 } \\
2 \text { 年を含む) }\end{array}$ & 中級レベル & \\
\hline ボブ & 男性 & 15 歳 & 中学 2 年の頃から 2 年間 & 中級レベル & \\
\hline ピーター & 男性 & 16 歳 & 小学 6 年の頃から 5 年間 & 上級レベル & \\
\hline
\end{tabular}

プライバシー保護のため、調査協力者の名前は仮名である。

インタビューは、2012 年 4 月と 5 月に実施し、1）日本語学習を始めたきっかけ、 2 ）香港日本語学校での学習体験、3）将来日本語をじのように使っていきたいか を中心にそれぞれ 1 時間半ずつ日本語で行った 10

データの分析では、まず全てのインタビュー・データを文字化したものを読み込 みながら、調査目的である調査協力者らの日本語学習の経験と意識についてカテゴ リーを生成した。その後、調查協力者の語りから浮かび上がってきた複数のテーマ に分類し、分析を行った。インタビュー・データから直接本文に引用した箇所は 「」です。

1 インタビューを日本語で行った理由として、筆者が調查協力者らの母語である広東語が話せなかったことが ある。英語か日本語でインタビューすることを調査協力者に尋ねたところ、どの学習者も日本語で話したい と言い、もし表現しきれないところがあった場合には英語での受け答えを行うことにした。実際には、イン タビュー中は全て日本語でやり取りが行われた。 


\section{4. 分析}

調査協力者らは全員アニメやマンガ、ゲームといった日本のポップカルチャーか ら日本語に興味を持ち、日本語学習を始めた。どの協力者も最初インターネットな どを使い日本語を学習していたが、「(語学) 学校で勉強するのは、自分で勉強す るよりもっと効果ができると思い」（ジャック）、香港日本語学校に通うようにな った。

私、アニメとか、興味があるので、いろいろ見るんですよね。それで、何か会話が 少し覚えられて、それから何か正式に勉強しようかなと思って、この学校に入りま した。(アリス)

「正式」な勉強と語るアリスではあるが、調查協力者らは日本語は「ツールでは なく、趣味」（ジャック）と語るように、日本語学習を将来の仕事や日本留学のた めといった文化資本を獲得蓄積するための投資（Norton，2000）として捉えている わけではない。

興味だけで、日本語を習っているから、将来日本語を使う仕事は別に思わないです よね。（アリス）

私達は、日本語の勉強が趣味だから、そういう（日本語能力試験といった）テスト は、必要ではないと思います。(ジャック)

日本語（の学習）が、ただ、たぶん好きだから、始まったので、別に将来の仕事と か、将来の生活とかにかかってないというか、そういう関連が、あるから始まるわ けではないし、ただ、あのう、好きだから。（ピーター）

また、調査協力者らが将来大学で学習したい専攻は、医療（レーチェル）、物理 （ジャック）、心理学（ピーター）といった日本語を必要としない科目であり、ま だ専攻を定めていないアリス、ボブも漠然と経済学を希望していた。日本研究など の日本や日本語に関係する学問に興味はないのか尋ねたところ、「日本研究も興味 があるが、やっぱり、もっと好きが物理です」（ジャック）や「日本研究は難しい イメージがあって、それよりも心理学に興味がすごくあって、心理学の勉強がした いです」（ピーター）と述べ、日本や日本文化、日本語についてさらに研究をした り日本語を職業に生かしたりしたいという声を聞くことはなかった。また、日本へ 


\section{瀬尾 匡輝：香港の民間語学学校で日本語を学習する高校生達の学び}

一構成主義の視点から一

の進学についても尋ねたところ、両親が日本語を就職や進学、日本定住を目的とし て投資（Norton，2000）することの難しさを調査協力者らに示唆しているようであ り、香港の大学への進学を希望していた。

両親とかのアドバイスとかもらって、それは日本語が好きというのはわかっている んですが、やっぱり香港での大学の学位をちやんと取った後に自分の好きな方向に 進んでもいいですけど、成績につく学位が取れたら、取れた上で日本語について深 く勉強できるので、考えたんですけど、それは。香港での大学の勉強が終わった後 に決めたいと思います。（ピーター）

私は日本へ行きたい。でもね、母さんに言われたんだよ、「日本語では好きな仕事 ができないかもしれないよ。」って。だから、香港の大学かなあ。（アリス）

このように調査協力者らは日本語を文化資本とする必要性を感じておらず、また 文化資本になりにくいと考えているようであった。そのように考える調查協力者ら は、日本語学習を「勉強」として捉えるわけではなく、彼・彼女らの興味の対象で あるアニメやマンガ、ゲーム、日本のバラエティ番組といった日本のポップカルチ ヤーを通して日常的に触れる楽しみと理解し、学習をしている。

（日本語の勉強は）毎日。アニメ見る。座って書いたり、覚えたりはしない。で も、タイプはする。友達と Facebookで。（ボブ）

勉強しない。授業以外はあんまりしないでしょ。まあ、普段はアニメとか、たまに 見るですけれども、それは勉強に・・・・なるのかもしれない。そうね、なるかも しれない。普通に本を勉強するとかは、私達はしないね。（アリス）

毎日は、こうやって（書いたり、文型を覚えたりする）勉強はないんですけど、や つぱりウェブとかはいろいろ見るのが好きなので、後は学校の宿題もやりたくない し、それで（日本のバラエティ番組を）いろいろ見るようになって、もしお母さん が、「まだ宿題を終わってないの」と聞かれたら、「日本語の勉強を一応やってま す」という言い訳ができて。毎日 1 時間くらいはいろいろ見てます。普通に香港の テレビを見ていないので、エンターテイメントの時間が日本語の勉強になるという か。（ピーター） 
このような学びの環境では、日本文化や日本語の知識そのものを蓄積することよ りも「日本語の勉強で学んだこと（日本語の学習を通して得られた学び）」を生か したい（ピーター）と考え、日本語学習を通して得た「人間としての成長」（ピー ター）を重視していた。それは、「日本語自身ではなく、‥日本語の勉強で（を通 して）学んだこと、例えば自分でもやればできるという」（ピーター）ことであり、 日本語を学習することにより得られた自身の中での成長であったり、周りとの関係 性である。特に、調査校である香港日本語学校では、調查協力者らは社会人と共に 学ぶことにより、社会人らの人生経験や同年代とは異なる学習意欲などから新たな 知見を得、自身の理想とする将来像を描いていた。

彼ら、彼女ら（社会人学習者）と話すときは、新しい日本語以外の何かを習えると 思います。人生経験みたいな。…(例えば、) クラスにテレビのレポーターさんが いまして、いろいろ聞いたんですよ、ジャーナリズムのこと。いろいろ勉強になり ました。（アリス）

（自分が理想とするクラスメートは）結構若いんですけど、家族とか、仕事だった り、寸ごくがんばっていると思うので。‥ここのクラスでは、あのう、彼がムード メーカーなので、はい。おもしろいし、先生とのやりとりというか、すごくおもし ろかったので、別にすごく偉い人ではないと思うんですけど、それが、どこに行っ てもみなさんを人を楽しくさせるというのが、そういう力というのがすごく羡まし くて、自分もそういう人になりたいです。（ピーター）

そして、彼・彼女らの通う高校では、「競争が激し」く（ピーター）、また同年 代の学生同士のため「遊んでしまう」（ジャック、ボブ）こともあるが、香港日本 語学校では、「楽しい雾囲気だけれども、何か勉強したいという気分が強」く（ジ ヤック）、「（日本語学習で）くじけそうな時も一緒にがんばろうという雾囲気」 があるという（ピーター）。このような䨌囲気の中では、共に日本語を学習寸ると いう仲間であるという意識が自然と出来上がっており、年齢差を越えた関係性が構 築されている。また、年齢や社会経験の異なる学習者同士ではあるが、日本語能力 に限って見た場合では、アニメやマンガを通して学習寸る調查協力者らのほうが 「成績がいい」（アリス）、「日本語が上手」（ピーター）ということもあり、時 には従来の年齢による力関係が逆転することもある。そのような関係性には不思議 と思いつつも、喜びを感じている。 
（日本語の授業以外の）他の活動だったら、大人というのは先生だけなので。周り の先生だったり、学校の先生だったり、日本語のクラス以外で別に大人と接するの はないです。（ピーター）

（同じ日本語学習者として大人と接するのは）不思議ですよね。同じ教科書で、大 人のみなさんが、文法を理解できなかったときに、私がちょうどその時わかったの で、なんていうんですか、そこだけはすごいと思うので、何かうれしいというのも あるし。（ピーター）

大体、私達のほうが日本語が上手ですよね。ま、大人は他のことばを習うのはちょ っと難しいではありませんでしょうか。仕事は大変だし、忙しいし、彼らにとって 日本語は全く新しいことばですから、それは難しいと思いますね。（アリス）

このように日本語能力の高さから協力者らが優位になることはあるが、それを理 由に大人を見下したりすることはなく、「大人だけが（日本語の学習が）できるこ とでもない」と理解をし、「負けたくない」（ピーター）という気持ちを強め、対 等な力関係での日本語学習を望んでいた。

そして、このような力関係の逆転は学習者である大人との間だけではなく、日本 語非母語話者である香港人教師との間にも起こっている。

最初は私達が、私たちの趣味の中の日本語を先生に聞いたから。でも、先生はその ことばを全然知りません。そして、毎週は、私たちのことばを先生に教えた。 ヤツク)

しかし、教師が日本語のことばを知らないからといって、その教師への信頼を失 ったわけではなく、よりお互いの知識を共有することができる「友達になった」 (ジャック）。

私達は、アニメから、たくさん最近のことばを知っている。そして、先生は、普通 のことばはたくさん知っている。だから、お互いに勉強できる。だから、時間がだ んだん、話す時間が増えました。そして、お互い、今は何をしているか、話してい る。(ジャック)

香港で日本語を学ぶ調査協力者らにとって、日本人と接することは皆無ではある が、このように自分が尊敬できるクラスメートや日本語非母語話者である日本語教 師との関係性を構築し、日本語を使用するコミュニティを形成しているのである。 
さらに、年齢差や力関係があるとされる人々との関係だけではなく、調查協力者 らの高校で日本語を理解する友達とも日本語を使い会話をするコミュニティを形成 していった。

今は、たぶん睱なときは、暇なときも、今年 N1 を受ける友達もいます、「最近何 を勉強していますか」と聞いたら、「忘れた」と言うんですが、そういう会話とか は日本語でやったり、日本語の圥談を言ったり、そして、他の友達が全然わからな いときがあるから、すごく楽しいです。（ピーター）

友達との会話。秘密があると、日本語で話しているのは、他の人は、わかりません ので、それは秘密になりました。(ジャック)

友達と日本語を話すは、おもしろい。（ボブ）

このように、日本語非母語話者同士ではあるが、お互い日本語を使いやりとりす ることで、「日本語の練習」（ジャック、ピーター、ボブ）以上に、やりとりを通 し日本語を使う仲間という帰属意識が形成されているのではないだろうか。そして、 そのような “学び”の場が学習者にとってとても心地のいいものであり、「楽し い」、「おもしろい」という気持ちをさらに強めているのである。

\section{5. 考察}

構成主義の学習理論では、知識や学習を以下の 3 つの視点から捉えている。

1）学習とは学習者自身が知識を構築していく過程である

2）知識は状況に依存している

3）学習は共同体の中での相互作用を通じて行われる

(Resnick, 1989, cited in 久保田, 2000)

従来の客観主義では、学習とは学習者への知識の効果的な移転であると考えられ、 知識は 1 つ 1 つ学習者にとって吸収しやすいように再構築・細分化され、易しいも のから難しいものへと順番に導入されていた。しかしながら、そのような学びでは、 実際に知識が置かれている状況と教えられている知識が結びつかず、学習者は必要 な場面でもその知識を使うことができない。一方、構成主義では、個々の学習者が 主体的に学習活動に参加し、自ら知識を構築していくことが必要とされ、知識はそ の参加過程で学ぶという認識である。そして、その学習は他の学習者と切り離され 孤立した状態で行われるのではなく、同じ共同体に属寸他の学習者らとのかかわり 


\section{瀬尾 匡輝：香港の民間語学学校で日本語を学習する高校生達の学び}

一構成主義の視点から一

の中で行わなければならないのである。そのため、そこでの学びは今現在問題解決 しなければならない状況におかれた学習者らが他者とのやりとりを通して学びを進 めるものであり、将来のためというよりはまさに“今ここ”で起こる学びなのであ る。

本調査でも、調査協力者らは将来の仕事のための文化資本を獲得蓄積する投資 （Norton，2000）として日本語学習を捉えていなかった。また、教科書や授業が提 示する知識を体系的に学習してはいなかった。それよりも、むしろ今現在調査協力 者らが接しているアニメや漫画、ゲーム、バラエティ番組といった日本のポップカ ルチャーから日本語を学び、それを重視していた。そして、「座って書いたり、覚 えたり」する勉強はしないが、実際にアニメや漫画、ゲーム、バラエティ番組を楽 しみながら、自身の楽しみのために必要な興味や関心ごとに対しての日本語を積極 的に取り入れようとしていたのである。

そのような学びの中での日本語クラスの役割とは、「わからないことば」を紹介 してもらうことであり、それ以外は担任教師やクラスメートとの積極的なやりとり を重要視しているようであった。年龄や社会経験が全く異なる学習者同士であるに も関わらず、共に尊重し合い学びあう関係性がクラスメートや教師との間で構築さ れていた。そして、その学びは日本語に関する学びだけではなく、日本語学習を通 した別の学び、例えば自分の理想とする将来像を構築するといったものであった。 本来、調査協力者らにとって絶対的権威であった大人や教師が、時には自分と同じ 立場や逆転した立場になることで、コミュニティ内での学びあいが促進されていた。 そして、そのコミュニティを教室内だけではなく、高校の友達と日本語を話すなど 教室外でも能動的に形成していたのである。

また、調查協力者の間には、日本語母語話者の存在がなく、また敢えて求めても いなかった。日本人との接触が極めて少ない香港では、インターネットやテレビな どのメディアを介して提供されるアニメや漫画、ゲーム、テレビ番組の日本語が消 費の対象となっているようだ。このような日本語を通じて学習する香港の学習者に は、従来の日本人との接触やコミュニケーションを目的とした教育観やことばの学 習・習得を目的としたコミュニケーション活動が学習者の学習スタイルには十分対 応しきれなくなっているのではないだろうか。それよりも、本調査の協力者らが述 べたように、日本語そのものを学習するのではなく、日本語を通した学びがより必 要とされており、今後海外における日本語教育のあり方をさらに検討する必要性に 迫られているだろう。 


\section{6. おわりに}

このように本調查に協力してくれた香港の民間日本語学校で学ぶ 10 代の日本語学 習者達は、自らの手によって構成主義の学習理論に基づく学習や知識の構築を行っ ていた。しかし、一方で日本語の授業の多くは、学習者への効果的な指導法ばかり に焦点が当てられたり、教師による一方的な日本文化・日本語の知識の伝達にはな っていないだろらか。確かに、現在の学校教育の枠組みは近代化に伴い発展してき た社会システムであるという歴史的経緯から客観主義に基づいているため（柳， 2005）、構成主義の学習理論を取り入れることは難しい。しかしながら、学校教育 の枠組みが学習指導要領などにより徹底されている初等・中等教育に比べ、大学な どの高等教育や生涯学習機関である語学学校では構成主義の学習環境をデザインし や寸いのも事実である（久保田，2012）。特に、今後このような 10 代の学習者が大 学へ進み、生涯学習として日本語を勉強し続けることを考慮すると、今後そのカリ キュラムを再考していく必要があるのではないだろうか。また、情報通信技術の発 達により、今後益々情報の行き交いが活発になるであろうグローバル化社会では、 このような学習者の存在を無視することはできなくなってきている。この流れにお いて、今後香港の日本語教育が更なる発展を遂げるためには、教師らも日本語母語 話者・非母語話者、研究者・実践者、大学教員・語学学校教員、ベテラン教師・若 手教師、プログラム主任・現場教師といった 2 項対立で物事を捉えるのではなく、 現場に携わるものの全てが連携をし、その中で自らも構成主義の立場に立った学び あいを通して、このことについて検討していかなければならないであろう。 


\section{瀬尾 匡輝：香港の民間語学学校で日本語を学習する高校生達の学び}

\section{一構成主義の視点から一}

\section{参考文献}

有田佳代子（2008）「構成主義と日本語教育」『敬和学園大学研究紀要』17, pp. 267-282

有元典文（2001）「社会的達成としての学習」『人はいかに学ぶか』中央公論社

国際交流基金(2011a)『海外の日本語教育の現状日本語教育機関調査・2009 年＼cjkstart概要』

$<h t t p: / / w w w . j p f . g o . j p / j / j a p a n e s e / s u r v e y / r e s u l t / i n d e x . h t m l>（ 2013$ 年 1 月 16 日）

国際交流基金（2011b）『日本語教育国・地域別情報２011 年度 ＜香港＞』

$<$ http://www.jpf.go.jp/j/japanese/survey/country/2011/hongkong.html> （2013 年 1 月 16 日）

久保田賢一（2000）『構成主義パラダイムと学習環境デザイン』関西大学出版部

久保田賢一（2012）「第 1 章＼cjkstart構成主義の学習理論」久保田賢一・岸磨貴子編『大学教育をデザイ

ンする一構成主義に基づいた教育実践』晃洋書房 pp. 14-31.

瀬尾匡輝（2011）「香港の上級の日本語生涯学習者の動機づけ一学習者の日本語ヒストリーから動 機づけを探る」『アジア日本研究』1，pp．11-25.

瀬尾匡輝・山口悠希子（2012）「インフォーマル・ラーニング下における日本語学習一独学で日本 語能力試験 N1 に合格した学習者達を事例として」『第 9 回国際日本語教育・日本研究シンポジウ 么予稿集』<http://www.japanese-edu.org.hk/sympo/upload/manuscript/20121015051126.pdf>（2013 年 1 月 16 日）

宮崎紀子（2011）「香港の中等教育における新しい時代の日本語学習への提言一順徳聯誼総會翁祐 中學の事例から」『日本学刊』14, pp. 159-175.

柳治男（2005）『<学級 $>$ 歴史学一自明視された空間を疑う』講談社

梁安玉（2012a）「2011 年度活動報告（2011 年 1 月～12 月）」『日本学刊』15，pp．1-3.

梁安玉（2012b）「香港新高中日語課程及中學日語教育現況問卷調查報告（2010-11 年）」『日本 学刊』15, pp. 149-169.

Norton, B. (2000). Identity and language learning: Gender, ethnicity, and educational change. London: Longman/Pearson Education.

Resnick, L.B. (ed.). (1989). Cognition and instruction: Issues and agendas. Hillsdale, NJ: Lawrence Erlbaum Associates.

Richards, K. (2003). Qualitative inquiry in TESOL. New York, NY: Palgrave Macmillan.

Steffe, L.P. \& Gale, J. (1995). Constructivism in Education, Lawrence Erlbaum Associates, Publishers. 